\title{
Pembiasaan Cuci Tangan yang Baik dan Benar pada Siswa Taman Kanak-Kanak (TK) di Semarang
}

\section{Good Habit and Proper Handwashing Counseling for Kindergarten Students in Semarang}

\author{
Rohmat Suprapto ${ }^{1}$, Mardiyan Hayati ${ }^{2}$, Silvia Nurbaity ${ }^{3}$, Fitri Anggraeni ${ }^{4}$, Satria \\ Haritsatama ${ }^{5}$, Tsamarah Qaulan Sadida ${ }^{6}$, Almah Firoh ${ }^{7}$, Flandita Alri Pratama ${ }^{8}$ \\ ${ }^{1}$ Program Studi Pendidikan Matematika, ${ }^{2,3,4,5,6,7,8}$ Program Studi Kesehatan Masyarakat \\ Universitas Muhammadiyah Semarang, Kota Semarang, Indonesia \\ 1rohmat@unimus.ac.id, ${ }^{2}$ mardiyanhayati@gmail.com, ${ }^{3}$ silviabaitysilvia@gmail.com, \\ fitriaanggraenii11@gmail.com, ${ }^{5}$ satriaharitsatama@gmail.com, \\ tsamarahqaulan1823@gmail.com, ${ }^{8}$ alripratama888@,gmail.com,
}

Riwayat Artikel: Dikirim 2 Maret 2020; Diterima 10 Mei 2020; Diterbitkan 20 Mei 2020

\begin{abstract}
Abstrak
Penelitian ini bertujuan untuk memberi penyuluhan kepada anak-anak TK ABA 48 Semarang agar memiliki cuci tangan yang sehat dan bersih. Metode yang dilakukan melalui (1) penyuluhan/ceramah, (2) video pembelajaran, (3) praktik langsung. Responden sebanyak 23 anak. Didapatkan hasil 74,0\% bahwa anak-anak tidak terbiasa cuci tangan sesuai protokol kesehatan dan $26 \%$ yang sesuai standar kesehatan. Setelah dilakukan penyuluhan dengan tiga metode terdapat perubahan pengetahuan dan sikap dalam mencuci tangan yakni yang semula $26 \%$ meningkat menjadi 56,5\%. Kesimpulannya, pembiasaan mencuci tangan sesuai standar WHO dapat berhasil dengan jika melalui tiga langkah, cermah, alat bantu pembelajaran audio visual dan praktik langsung dengan air mengalir.
\end{abstract}

Kata kunci: hidup bersih dan sehat, cuci tangan yang benar, penyuluhan, audio visual, air mengalir.

\begin{abstract}
This study aims to provide counseling for kindergarten $A B A 48$ Semarang children to have healthy and clean hand washing. The method is done through (1) counseling / lecturing, (2) video learning, (3) hands-on practice. Respondents were 23 children. The results obtained $74.0 \%$ that children are not accustomed to washing hands according to health protocols and $26 \%$ that conforms to bealth standards. After counseling with three methods there was a change in knowledge and attitudes in washing hands, which from $26 \%$ increased to $56.5 \%$. In conclusion, babituation to wash bands according to WHO standards can be successful if through three steps, a mirror, audio visual learning aids and direct practice with running water.
\end{abstract}

Keywords: clean and healthy life, proper hand washing, counseling, audio visual, running water.

\section{PENDAHULUAN}

Sejak dunia dihebohkan dengan munculnya wabah covid-19 yang berawal dari Wuhan China pada Desember 2019, hingga kini virus ini masih menjadi pandemi global. Menurut Badan Kesehatan Dunia (WHO) Secara statistik per 17 Mei 2020 terdapat 4.535.731 (empat juta lima ratus tiga puluh lima ribu tujuh ratus tiga puluh satu) kasus positif Covid-19 dan sebanyak 307.537 (tiga ratus ribu lima ratustiga puluh tujuh) meninggal dunia di seluruh dunia (www.covid19.who.int) . Ini menandakan bahwa penyebaran virus corona ini merupakan pandemi global yang amat masif.

Kini semua orang tertuju pada upaya pencegahan dari terjangkitnya virus yang hingga kini belum ada anti-virusnya. Salah satu strateginya adalah adalah dengan mencuci tangan sesuai aturan kesehatan berdasarkan protokol WHO. 
Menurut Peraturan Menteri Kesehatan Republik Indonesia No. 3 Tahun 2014 (2014: 4) mencuci tangan yang benar adalah salah satu unsur dari tiga pilar pembangunan Indonesia bidang kesehatan yakni berpola hidup sehat. Sedangkan pilar yang lain adalah pengkondisian lingkungan sehat serta penyediaan layanan kesehatan yang representatif dan terjangkau semua kalangan.

Ihtiar untuk mensosialisasikan bagaimana tata cara agar anak-anak didik pada sekolah TK gemar membersihkan tangan adalah sebuah langkah yang amat penting. Menurut Megawati, dkk (2018: 40) pada usia ini, anak-anak belum terbentuk system imun dengan baik sehingga mudah tertular penyakit.

Langkah kongkrit dari usaha ini adalah berupa penyuluhan atau pemberian informasi pengetahuan (transfer of knowledge), pembiasaan yang baik (good habit) sejak dini disertai pendampingan atau praktik langsung dengan video pembelajaran. Langkah ini adalah sebuah keniscayaan guna menghadang agar covid-19 tak makin meluas.

Tujuan yang ingin dicapai dari penyuluhan cuci tangan yang baik dan benar ini adalah para siswa Taman Kanakkanak (TK) dapat memahami tata cara, dan dapat mempraktikkan bagaimana cuci tangan yang baik dan benar.

Diharapkan setelah pelaksanaan dari program di atas adalah terdapat perubahan perilaku di masyarakat, utamanya siswa-siwi agar mereka gemar mencuci tangan sesering mungkin dengan baik dan benar.

Sebagaimana telah menjadi pengetahuan umum (well-known) tangan adalah anggota badan yang kerap membawa dan menularkan bibit penyakit. Bahkan penyebaran covid-19 ini juga salah satunya melalui tangan. Jika terkontaminasi dengan penderita, maka tangan yang telah terkontaminasi akan menyentuh hidung, mata dan mulut. Dari tiga aera ini, maka covid-19 akan masuk ke organ paru dan kemudian virus akan merusak sistem paru yang pada akhirnya membuat seseorang sesak nafas dan jika system imun nya rendah, maka akan menyebabkan gagal pernafasan. (www.alodokter.com).

Mencuci tangan dengan sabun menurut WHO adalah cara yang tepat sesuai kesehatan (www.who.int), hal ini menurut Riris (2009: 2-3) karena sabun dapat membunuh kuman atau virus yang menempel di tangan. Maka usaha yang paling sederhana untuk menegakkan pilar hidup sehat adalah dengan gemar cuci tangan. Usaha yang oleh masyarakat dianggap sepele ini ternyata dapat ber kontribusi penting pada upaya pencegehan covid-19 (Ibrahim, dkk, 2020: 192).

Tangan adalah bagian tubuh kita yang paling banyak tercemar kotoran dan bibit penyakit. Ketika memegang sesuatu, dan berjabat tangan, tentu ada bibit penyakit yang melekat pada kulit tangan kita. Telur cacing, virus, kuman dan parasit yang mencemari tangan, akan menpel pada orang lain yang kita ajak berjabat tangan atau bahkan saat kita makan dengan tangan yang tidak bersih, kotoran tertelan dan sudah barang tentu akan menggangu pencernaan. (Retno dkk, 2013: 123).

Selain bertransmisi melalui tangan, kotoran, penyakit serta virus pada umumnya juga dapat melekat pada barangbarang lain seperti gagang pintu, uang, alatalat makan, juga permainan. Ketika alat-alat tadi dipegang dan kemudian tangan tidak dibersihakn maka akan sangat mungkin kita dapat tertular penyakit termasuk virus. (Kushartanti, 2012: 2-3). Maka mencuci tangan dengan benar dan sesuai kesehatan amatlah penting agar jenis virus dan penyakit tidak masuk ke dalam tubuh manusia.

\section{METODE}

Penelitian ini dilaksanakan dengan metode penyuluhan atau ceramah serta praktik dengan air mengalir. Dilaksanakan pada tanggal 9 Desember 2019 dan berlokasi di TK ABA 48 Semarang. Evaluasi juga 
dilakukan untuk mengukur tingkat pengetahuan dan efektifitas dari metode yang dipergunakan. Cara yang dipakai adalah berupa pemberian pertanyaan secara lisan dengan model tertutup. Teknisnya responden diberi pertanyaan sebanyak dua kali yakni sebelum dan sesudah penyuluhan berlangsung seputar pengetahuan tentang tata cara mencuci tangan sebagaimana standar WHO. Dari sinilah dapat disimpulkan apakah penyuluhan ini memiliki dampak signifikan atau tidak.

Guna meningkatkan efektifitas dan daya akurasi, penyuluhan juga mempergunakan media pembelajaran audio visual tentang prosedur cuci tangan yang sehat. Penggunaan media audio visual menurut Asmara (2015) akan membuat pembelajaran lebih berhasil bila dibandingkan dengan tidak menggunakan audio visual Senada dengan Hamdani, Cheppy Riyana (2007: 8-11) juga berpendapat sama bahwa bahwa strategsinya video pembelajaran karena berisi pengetahuan yang cukup lengkap dan mudah untuk dicerna peserta didik.

Pada proses penyuluhan dan praktik, peserta yang terdiri dari para anakanak TK ini akan dituntun untuk mempraktiktikkan 6 (enam) langkah cuci tangan yang baik dan benar menurut WHO. Langkah dimaksud adalah pertama telapak tangan digosok dengan sabun, kedua menggosok punggung telapak tangan secara bergantian kanan dan kiri, ketiga mensela-selai jari jemari juga dengan sabun, keempat ujung jari dicuci dengan bersih, kelima menggosok dan memutar ibu jari secara bergantian, dan yang keenam adalah letakkan semua ujung jari pada telapak tangan dan bersihkan dengan digosok secara perlahan menggunakan air mengalir. (www.who.int)

\section{HASIL DAN PEMBAHASAN}

Penyuluhan ini dilakukan di TK ABA 48 yang terletak di Jl. Zebra Tengah No.74, Pedurungan Kidul, Kec. Pedurungan, Kota Semarang. TK ini terbagi dalam dua kelas yaitu TK 0 besar yang terdiri dari kelas A dan B, dan TK 0 kecil yang terdiri dari Kelas A dan B. Pada penyuluhan ini kami memilih TK 0 besar kelas B sebagai responden berjumlah 23 responden.

Tabel 1:

Distribusi responden berdasarkan jenis kelamin di TK ABA 48 Semarang

\begin{tabular}{lcc}
\hline Karakteristik & Frekuensi & Presentase (\%) \\
\hline Jenis kelamin & & \\
\hline Laki-laki & 15 & 65,2 \\
\hline Perempuan & 8 & 34,8 \\
\hline Jumlah & 23 & 100 \\
\hline
\end{tabular}

Berdasarkan Tabel 1, dapat diketahui bahwa sebagian besar responden berjenis kelamin laki-laki yaitu sebanyak 15 anak $(65,2 \%)$ dan yang berjenis kelamin perempuan sebanyak 8 anak $(34,8 \%)$.

Tabel 2.

Distribusi responden berdasarkan pemahaman dan kebiasaan mencuci tangan di TK ABA 48 Semarang

\begin{tabular}{lcc}
\hline \multicolumn{1}{c}{ Kebiasaan } & Frekuensi & Presentase (\%) \\
\hline Kebiasaan baik & 6 & 26,0 \\
\hline $\begin{array}{l}\text { Kebiasaan } \\
\text { tidak baik }\end{array}$ & 17 & 74,0 \\
\hline Jumlah & 23 & 100 \\
\hline
\end{tabular}

Berdasarkan Tabel 2 di atas dapat diketahui bahwa pola mencuci tangan yang bersih dan benar hanya 6 anak $(26,0 \%)$, sebaliknya dengan kebiasaan tidak baik sebanyak 17 anak (74,0\%).

Dari data di atas, dapat diketahui bahwa sebagian besar anak-anak di TK ABA 48 Semarang belum mengetahui tata cara mencuci tangan sebagaimana tata aturan Badan Kesehatan Dunia (WHO), juga dapat juga dipahami bahwa anak-anak seusia ini belum mengetahui pentingnya 
cuci tangan dan berkebiasaan senang cuci tangan pakai sabun dengan 6 (enam) langkah sebagaimana telah di jelaskan di awal.

Juga dari tabel di atas dapat diketahui bahwa kebiasaan mencuci tangan sudah menjadi tradisi atau habbit di Kalangan anak-anak usia dini, namun problemnya ada pada kebiasaan yang baik atau good habbit ini belum sesuai tata kesehatan, jika ini tidak diberikan penyuluhan, maka akan menjadi kebiasaan yang kurang baik yakni hanya gemar cuci tangan akan tetapi tidak sesuai standar kesehatan, dan sangat mungkin setelah cuci tangan, kuman masih menempel.

\section{Gambar 1.}

Foto Saat Penyampaian Materi

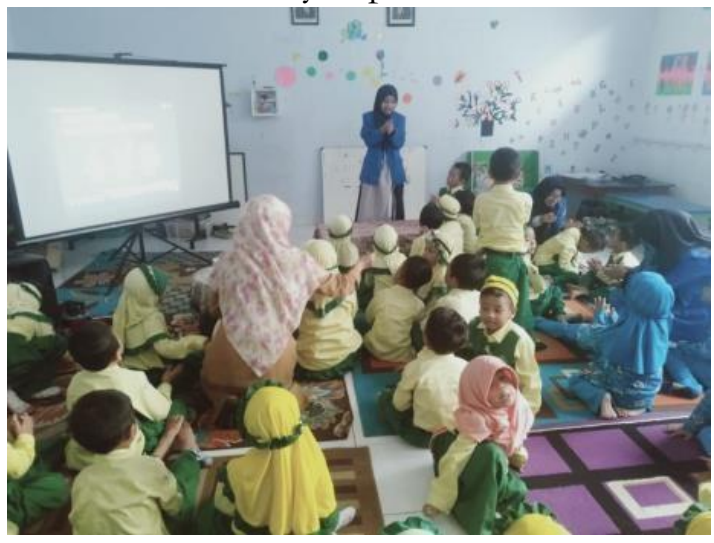

Sumber: Dokumentasi Pribadi

Pembiasaan cuci tangan sesuai standar kesehatan sesungguhnya dapat dilakukan dengan berbagai langkah. Selain melalui pembelajaran di sekolah oleh guru, juga dapat dilakukan oleh orang tua saat anak-anak sudah di rumah. Peran orang tua sangatlah penting, karena menurut Khalid Ahmad Syantut (2018: 8) orang tua adalah madrasah atau sekolah juga bagi anak-anak jika mereka sudah sampai di rumah. Karena orang tua adalah laksanaka sekolah, maka orang tua dapat juga melaksanakan transfer of knowledge (menyampaikan pengetahuan) selain tentu saja transfer of value (suri tauladan yang baik). Dari konsep ini orang tua amatlah memiliki peran yang sangat penting juga dalam memberikan pembelajaran sekaligus praktik menjaga kebersihan tangan sesuai langkah-langkah kesehatan. Selain itu, mereka juga memili peran penting dalam mensuasanakan kehidupan kesehatan berupa bersih tangan dari bibit penyakit yang sehat dan benar di keluarga sejak dini.

Gambar 2:

Foto Saat Nonton Bersama Video 6 Langkah Cara Mencuci Tangan yang Baik dan Benar

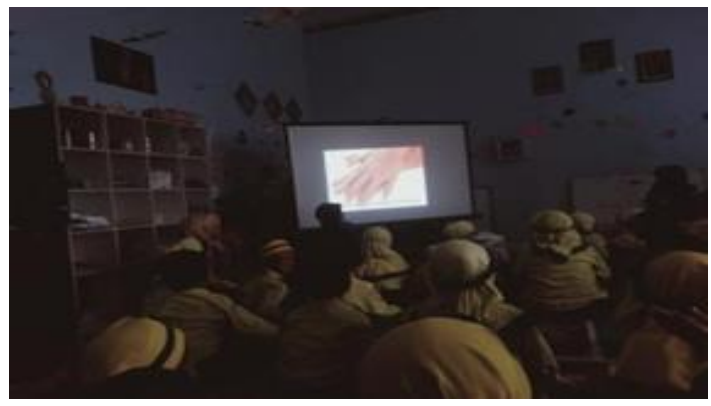

Sumber: Dokumentasi Pribadi

Jika ini dapat dilakukan maka anak akan memiliki pengetahuan tinggi tentang cuci tangan yang sehat dan benar. Namun orang tua kadang kurang menyadari atau bahkan belum mengetahui tentang bagaimana tata cara mencuci tangan yang sehat dan benar. Kondisi ini sudah barang tentu akan menjadi faktor penting bahkan dapat dikategorikan sebagai sikap yang tidak mendukung kebiasaan mencuci tangan sesuai standar kesehatan. (Riyanti, 2008). Menyadarkan orang tua juga menjadi pekerjaan yang tidak mudah membutuhkan waktu dan keseriusan dari beragai pihak.

Tabel 3.

Pengetahuan dan praktek responden setelah dilakukan penyuluhan di TK ABA 48 Semarang

\begin{tabular}{lcc}
\hline $\begin{array}{c}\text { Pengetahuan } \\
\text { dan Praktik }\end{array}$ & Frekuensi & Presentase (\%) \\
\hline Paham & 13 & 56,5 \\
\hline Tidak paham & 10 & 43,5 \\
\hline Jumlah & 23 & 100 \\
\hline
\end{tabular}


Berdasarkan Tabel 3 di atas dapat diketahui bahwa sebelum dilakukannya penyampaian materi terdapat $74,0 \%$ anak yang belum mengetahui cara mencuci tangan sesuai protokol WHO, maka setelah dilakukan penyuluhan dengan media video pembelajaran tata cara cuci tangan sesuai standar serta praktik dengan media air mengalir maka mengalami peningkatan yang cukup signifikan yakni sebanyak $56,5 \%$ anak telah mengetahui dan dapat mempraktikkan teknis mencuci tangan sesuai tata aturan yang benar.

Gambar 3.

Foto Praktik Cuci Tangan

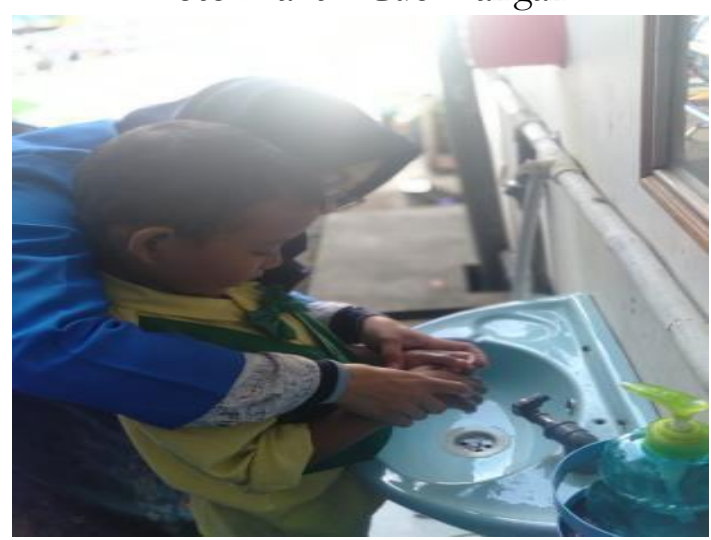

Sumber: Dokumentasi Pribadi

Gambar 4.

Foto Bersama

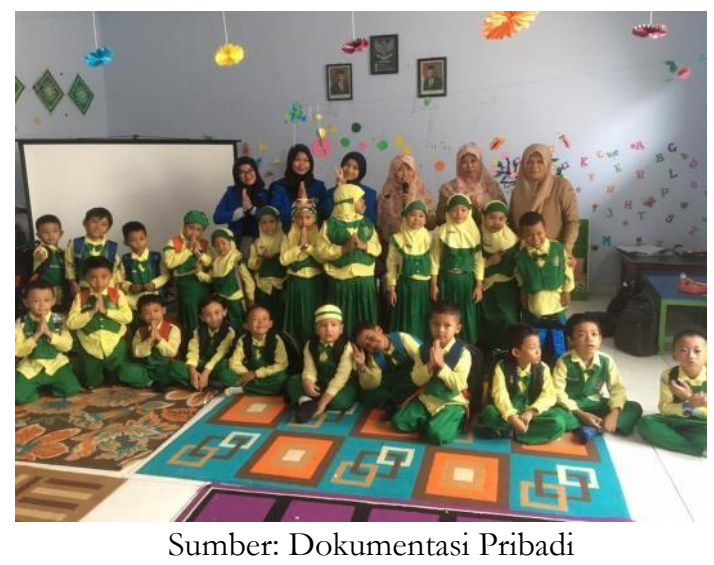

Kenaikan prosentasi pengetahuan anak-anak ini dapat disebabakan oleh media yang digunakan dalam penyuluhan ini. Yakni dengan video pembelajaran dan praktik langsung dengan air mengalir.
Variasi inilah yang menjadi factor meningkatnya pemahaman terhadap materi mencuci tangan ini. Dari tabel 3 di atas juga dapat dijelaskan bahwa pembiasaan berperilaku sehat dengan mencuci tangan pada anak usia dini nampaknya menjadi pekerjaan rumah semua pihak utamanya orang tua, cara paling efektif adalah dengan mempraktikkan langsung di rumah dengan air mengalir. Bagi keluarga muslim wudzu lima sebelum shalat lima waktu sudah lebih dari cukup untuk memberikan pembiasaan pada anak-anak tentang mencuci tangan itu amat penting. Barangkali yang perlu ditambahkan adalah saat wudzu sangatlah baik menggunakan sabun.

\section{Gambar 5:}

Foto Pemberian Plakat

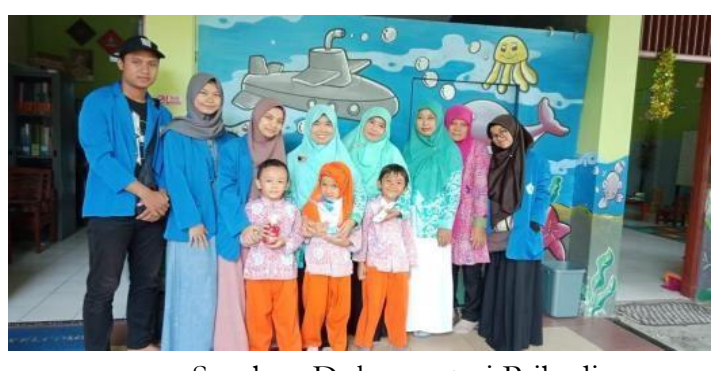

Sumber: Dokumentasi Pribadi

Gambar 6:

Acara Pelepasan di Aula FKM Lt. 4

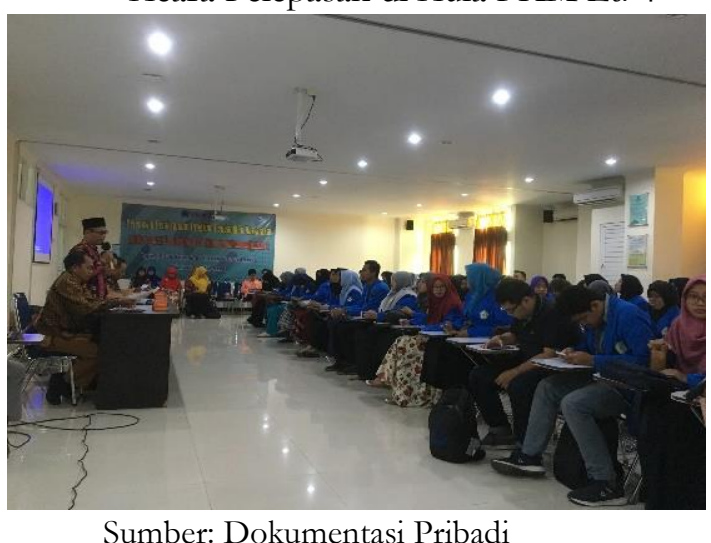

Kementrian Kesehatan RI (Depkes 2007) menyatakan bahwa anak-anak usia dini baik pra sekolah (TK) maupu usia sekolah dasar (SD/MI) adalah sasarn utama dalam implementasi hidup sehat. Hal ini karena anak-anak seuisia ini masih 
sangat aktif dan berkumpul, bermain bersama teman-temannya, tak jarang anakanak ini abai terhadap menjaga kebersihan badan utamanya mencuci tangan. Maka tak jarang mereka sangat rentan terhadap penyakit. Pembiasaan berpola hidup sehat harus terus digalakkan pada anak usia dini. Baik itu cuci tangan dengan sabun, memotong kuku atau menjaga lingkungan sekitar.

\section{KESIMPULAN}

Sebagian besar anak-anak usia dini khususnya di TK ABA 48 belum berperilaku benar dan sehat dalam mencuci tangan yakni sebesar $(74,0 \%)$, dan hanya $(26 \%)$ yang sesuai dengan standar kesehatan. Setelah dilakukan scenario langkah edukasi berupa cermah dengan media video pembelajaran dan praktik langsung, diperoleh peningkatan sebesar $(56,5 \%)$ anak telah mencu tanganya dengan sabun dan air mengalir.

Pentingnya pembiasaan menjaga kebersihan dan kesehatan fisik dengan salah satunya rutin cuci tangan dengan sabun dan air mengalir ini harus menjadi tanggungjawab bersam, baik sekolah dan juga orang tua. Diharapkan juga peran orang tua untuk memeberikan pemahaman tentang perilaku hidup bersih dan sehat dengan mengajarkan anak bagaimana cara mencuci tangan yang baik dan benar.

\section{DAFTAR PUSTAKA}

Asmara, A. P. (2015). Pengembangan media pembelajaran berbasis audio visual tentang pembuatan koloid. JURNAL ILMIAH DIDAKTIKA: Media Ilmiah Pendidikan dan Pengajaran, 15(2), 156-178.

Cheppy, Riyana. (2007). Pedoman Pengembangan Media Video. Bandung: Program P3AI Universitas Pendidikan Indonesia.
World Health Organization. (2020). WHO Coronavirus Disease (COVID-19) Dashboard. Retrieved May 17, 2020, from

https://covid19.who.int/?gclid=EAI aIQobChMI4taCysi76QIVDyQrCh0 IIgdKEAAYASAAEgJUR D BwE,

Liputan6. (2020). Tips Mencuci Tangan yang benar menurut WHO demi cegah virus corona covid19. Retrieved May 18, 2020,fromhttps://www.liputan6.com /bola/read/4219578/tips-mencucitangan-yang-benar-menurut-whodemi-cegah-virus-corona-covid-19

Alodokter. (2020). Virus corona. Retrieved May 27, 2020. From https://www.alodokter.com/viruscorona

Ibrahim, I., Kamaluddin, K., Mintasrihardi, M., Junaidi, A. M., \& Abd Gani, A. (2020). Bencana Virus Corona melalui Sosialisasi pada Anak Usia Dini pada Desa Rempe Kecamatan Seteluk Sumbawa Barat. Selaparang Jurnal Pengabdian Masyarakat Berkemajuan, 3(2), 191-195.

Kushartanti, R. (2012). Beberapa faktor yang mempengarubi perilaku cuci tangan pakai sabun (CTPS)(studi di Sekolah Dasar Negeri Brebes 3) (Doctoral dissertation, Program Pascasarjana Undip).

Megawati, A., Hastuti, E. D., \& Sari, D. E. M. (2018). Peningkatan Kualitas Kesehatan Anak Dengan Penerapan Cara Mencuci Tangan Yang Benar Dan Pengenalan Tentang Obat Kepada Anak Usia Dini. Jurnal Pengabdian Kesehatan.

PERMENKES. (2014). Retrieved June 1, 2020.

fromhttp://hukor.kemkes.go.id/upl oads/produk hukum/PMK $\% 20$ No. $\% 203 \% 20 \operatorname{ttg}^{0} \% 20$ Sanitasi $\% 20$ Total $\%$ 20Berbasis $\% 20$ Masyarakat.pdf

Hastuti, E. P., Aisah, S., \& Santosa, B. (2011). Hubungan Peran Orang Tua Dengan Kebiasaan Mencuci Tangan pada Anak Prasekolah di Taman 
Kanak-Kanak Siwi Peni Guntur Demak. FIKkeS, 4(2).

Purwandari, R., \& Ardiana, A. (2015). Hubungan antara perilaku mencuci tangan dengan insiden diare pada anak usia sekolah di Kabupaten Jember. Jurnal Keperawatan, 4(2).

Rachmayanti, R. D. (2013). Penggunaan media panggung boneka dalam pendidikan personal hygiene cuci tangan menggunakan sabun di air mengalir. Jurnal Promosi Kesehatan, 1(1), 1-9.

Ambarwati, E. R., \& Prihastuti, P. (2019). Gerakan Masyarakat Hidup Sehat (Germas) Mencuci Tangan Menggunakan Sabun Dan Air Mengalir Sebagai Upaya Untuk Menerapkan Perilaku Hidup Bersih Dan Sehat (Phbs) Sejak Dini. Celebes Abdimas: Jurnal Pengabdian Kepada Masyarakat, 1(1), 45-52.

Syantut, Khalid Ahmad. (2018). Mendidik Buah Hati di Rumah dalam Rumahku Madrasah Pertamaku, terj. Iman Martin, Maskana Media. 